\title{
Unemployment duration and workers' wage aspirations in Spain
}

\author{
Namkee Ahn \\ FEDEA
}

\author{
J. I gnacio García-Pérez ${ }^{\text {ay }}$ \\ U. Pompeu Fabra
}

March, 2000

\begin{abstract}
A bstract
This paper examines unemployed workers' declared willingness to work for a wage lower than the one warranted by their quali..cation. We analyze which personal and economic characteristics determine this willingness and how it changes as unemployment spells lengthen. Moreover, we also study the in $\ddagger$ uence of this willingness on unemployment duration. The main results are: (i) Young workers, those less educated and those living in regions with high unemployment show a more positive attitude towards accepting lower wages while married women with a working husband show more negative attitudes; (ii) The exhaustion of unemployment bene.ts has positive exects in the transition probability of the attitude from negative to positive; (iii) The exect of this attitude on the unemployment hazard rate is positive but only marginally signi..cant which may be showing that this willingness is not only refecting the worker's reservation wage but also some unobserved heterogeneity; (iv) The negative duration dependence of the unemployment hazard rate is substantially reduced when unobserved heterogeneity is controlled for.

K eywords: W illingness to work for lower wages, reservation wage, unemployment duration, unobserved heterogeneity.

J EL classi..cation: C41, J 64.

\footnotetext{
${ }^{x}$ We want to thank M anuel A rellano, Samuel B entolila, A driana K ugler and Pedro M ira for all their comments and suggestions, and Luis Toharia for providing us with the data set. Comments from seminar participants at CEMFI and Universitat Pompeu Fabra are also acknowledged. Of course, the usual disclaimer applies.

yA ddress for correspondence: Universitat Pompeu Fabra, Department of Economics and Business, C/ Ramón Trias Fargas 25-27 - 08005 Barcelona (Spain). e-M ail: ignacio.garcia@econ.upf.es.
} 


\section{Introduction}

According to the standard job search theory, longer unemployment duration entails an increasing probability of accepting job oxers. We may expect this fact to pull the unemployment rate down. But this theoretical prediction is suspected in a country like Spain, where the unemployment rate has been exceptionally high for a prolonged period, $20 \%$ on average in the past 10 years. The persistence of high unemployment in Spain has drawn much attention among policy makers and economists. Some studies have emphasized insuf..cient job creation from the labor demand side resulting in high structural unemployment (B entolila and Blanchard, 1990), and others have pointed to the lack of worker mobility or other aspects on the labor supply side (Blanchard et al., 1995 or A hn, de la Rica and Ugidos, 1999). We examine another aspect of labor supply, unemployed workers' willingness to work for a reduced wage and its relationship with their unemployment duration in Spain.

In Ahn et al. (1999) it is shown that the willingness to move for work is not sensitive to workers' unemployment duration, suggesting the lack of worker mobility as one of the underlying causes of Spanish unemployment. In this paper we examine the worker's $\ddagger$ exibility in terms of the reservation wage. We highlight how unemployed workers' willingness to work for a reduced wage changes with the duration of unemployment and also how this duration is axected by such willingness.

The willingness to work for a reduced wage can be considered as a reducedform variable which rełects the worker's reservation wage. Therefore, according to the standard job search theory, the willingness to work for a reduced wage should increase with the duration of unemployment, given other things constant along the unemployment spell, since reservation wages decrease with 
unemployment duration. ${ }^{1}$

We examine ..rst which personal and economic characteristics axect the willingness and how it evolves along the unemployment spell. We also examine the infuence of this attitude on the worker's probability of leaving unemployment. It is likely that there exist some unobserved variables (income, skills, ...) which can axect both reservation wages (hence the willingness) and unemployment duration. Therefore, in order to control for the possible endogeneity of the willingness, we estimate jointly two processes: one for the exit rate from unemployment and the other for the willingness.

M ain ..ndings are that young, less educated and those living in times or regions of high unemployment are more willing to accept a reduced wage. In the analysis of attitude changes, we ..nd that the probability of changing attitudes from negative to positive decreases with unemployment duration while the exhaustion of unemployment bene.ts increases this transition probability.

Regarding the exect of declared willingness on the probability of leaving unemployment, we ..nd a positive, but only marginally signi..cant, exect. The results suggest that the willingness variable is related not only to reservation wages but also to some unobserved characteristics which render both a lower unemployment hazard rate and lower willingness to work for a reduced wage. A nother interesting result of our study is that once we control for the presence of unobserved heterogeneity, negative duration dependence in the probability of leaving unemployment is substantially reduced, which is consistent with some theoretical suspicions. ${ }^{2}$

We organize the paper as follows. First, we present the main theoretical predictions which are relevant to the willingness to work for a reduced wage.

\footnotetext{
${ }^{1}$ See, among others, Mortensen (1986) or Van den Berg (1990) for this basic theoretical prediction.

${ }^{2}$ This result contrasts to that found in Bover et al. (1997).
} 
Second, we describe the data used in our analysis and in the third section we present the empirical results. In this section, we start by analyzing the determinants of the willingness, and we highlight its relationship with unemployment duration by estimating a model for the time it takes until initially unwilling workers become willing to work for a reduced wage. Finally, we estimate a model for the duration of unemployment as a function of, among other variables, the expressed willingness. The last section presents the main conclusions of the paper.

\section{Theoretical background}

First of all, it is important to describe clearly our variable of analysis. The question we analyze is, when translated literally, "A re you willing to accept a job oxer with a wage inferior to the one adequate for your quali..cation?" The answer to this question may be interpreted as a reduced-form variable related to the reservation wage. However, the interpretation of the other part of the question is not clear: $W$ hat is the adequate wage for one's quali..cation? Formally, we may write this willingness using the reservation wage, $w_{R}(t)$, and the adequate wage for quali..cation, $w^{a}$. The answer to the above question will be yes if $w_{R}(t)<w^{a}$, and no otherwise.

In order to understand this question better we can use a standard nonstationary search model. ${ }^{3}$ This model deals with the optimal stopping decision an unemployed worker has to take when searching for a job. It assumes that unemployed workers will accept any oxer if its associated wage is equal to or higher than their reservation wage. If the environment in which the worker is searching is non-stationary, in the sense that some of the parameters which describe the market change over time, his reservation wage

\footnotetext{
${ }^{3}$ See M ortensen (1986) or Devine and K iefer (1991) for extensive surveys of the literature.
} 
will also change over time. For example, if income or job oxer frequency decreases with unemployment duration, the reservation wage will decrease as well (see Van den Berg, 1990 or García-Pérez, 1998). T herefore, these models provide us with one theoretical relationship between the duration of unemployment and reservation wages: given other things equal, the probability of observing $w_{R}(t)<w^{a}$ increases with unemployment duration because the reservation wage decreases. However, there is another element that axects the unemployed worker's willingness. What is the perceived adequate wage for her quali..cation, $w^{\text {a }}$ ? It seems reasonable to assume that this is related with the average wage received by workers with similar characteristics. If this average oxered wage were not axected by unemployment duration, we should expect a greater willingness to work for a reduced wage over unemployment duration. However, some factors, such as skill depreciation during unemployment, could make workers adjust downward their $w^{a}$ as their unemployment spells lengthen. Final exects will depend on the magnitude of each of these factors.

Reservation wages depend on the unemployed worker's liquidity constraints and her expectations about future job oxers, as well as search costs. Liquidity constraints depend on unemployment bene.ts and savings or accumulated assets (empirical evidence is shown in Stancanelli, 1999). The bigger the latter are the less likely is the worker to accept a job oxer with a reduced wage. Those with greater family responsibilities are likely to have lower reservation wages. The composition of the household and each household member's situation, such as the presence of young children and the numbers of working or unemployed members, are also likely to be relevant factors. Also relevant are individual preferences for work, which are not observed but may be captured by certain individual characteristics such as age, education 
and place of residence.

Reservation wages are also likely to be axected by the extent of human capital lost during unemployment spells. Those who face more rapid skill depreciation while unemployed will be more willing to accept a reduced wage oxer. In this respect, occupation and educational level might be relevant variables. The current economic situation and expectations about future economic conditions also axect one's willingness to accept a reduced wage. For example, during a recession, when oxers arrive less frequently, job oxers are more likely to be accepted than during a period of expansion.

F inally, the willingness to work for a reduced wage will also depend on how one's future career and wage prospects are axected by current wage levels or employment status. It is likely that a low current wage may axect future wage prospects negatively if it operates as a negative signal to employers. This may be more serious among occupations of high skill and high education, thus making workers with these characteristics less willing to work for a reduced wage.

\section{Data and variables}

The data used in this study are taken from the Spanish Labor Force Survey (EPA) which is the main source of labor market information in Spain. This survey is undertaken each quarter on about 60,000 households (about 200,000 individuals). One-sixth of the sample is replaced by new households each quarter. Therefore a household, once chosen, is interviewed up to six times over an interval of about 18 months.

In the ..rst part of analysis where we examine the determinants of the willingness to work for a reduced wage, we use pooled cross-section data over the 17 quarters between 1992:1 and 1996:1. In the second and third part 
of analysis where we examine the relationship between the willingness and unemployment duration, we construct individual longitudinal data from the EPA's rotating panel from 1992:1 to 1997:2. The individuals interviewed for the ..rst time in the ..rst quarter of 1992 had their last interview in the second quarter of 1993 and similarly, the last cohort of our sample was interviewed from the ..rst quarter of 1996 to the second quarter of 1997. Thus, we capture in our data set the last recession of the Spanish economy and the following expansionary period.

We restrict our sample to those workers whose unemployment duration at the time of the ..rst interview is shorter than four months, mainly in order to reduce the potential unobserved heterogeneity bias that could be contained in the dixerent unemployment duration observed at the start of interviews, that is, the problem of left-censoring.

In our sample about $70 \%$ of responses to the willingness question were at rmative, $20 \%$ negative and $10 \%$ indecisive. A ..rst look at the responses over time suggests that the willingness to work for a reduced wage is countercyclical: during recessions unemployed workers are more willing to accept lower wages than during periods of expansion. ${ }^{4}$

The dependent variable for the second part of the study is the duration, in quarters, until initially unwilling workers become willing to work for a reduced wage. That is, we estimate the hazard rate of changing the attitude from negative to positive.

Finally, we study the exects of the expressed willingness to work for lower wages on unemployment duration. Since the willingness is endogenous with respect to the probability of ..nding a job, we jointly estimate two processes.

\footnotetext{
${ }^{4}$ According to the EPA, in 1992 , when the unemployment rate was $17 \%$, about $60 \%$ of the unemployed were willing to work for lower wages. In 1995, the year with a $25 \%$ unemployment rate, this proportion was over $75 \%$.
} 


\section{Empirical results}

\subsection{Determinants of the willingness to work for lower wages}

In an empirical and reduced-form context, the willingness to work for a reduced wage can be speci..ed as a latent variable representing the dixerence between the reservation wage and the adequate wage for the worker's quali... cation, $w_{R}(t) i w^{a}$; and can be considered as a function of some explanatory variables. However, what we really observe is a discrete outcome y; where, in our case, $y=1$ if an individual is willing to work for a reduced wage and $y=0$ otherwise. Assuming the extreme value distribution of the error term in the speci...cation of this variable, we can estimate a logit model on it. ${ }^{5}$ Table 1 presents the results of this estimation.

(Table 1)

In this table we have the sample mean of each explanatory variable, estimated odds ratios and asymptotic $t_{i}$ ratios of parameter estimates. The model is estimated separately for the male and female samples to capture possible dixerential exects of explanatory variables by gender. The odds ratios are interpreted as the relative probability corresponding to a unit increase in each covariate. We now discuss some important results.

Family Characteristics: We have included a variable representing whether the individual is the head of household, and also the head's employment status for non-heads. It does not show any signi..cant exect among males, while a wife whose husband is working is less willing to work for lower wages than other females. This suggests that wives with an employed husband would have higher reservation wages than those with an unemployed or inactive

\footnotetext{
${ }^{5} \mathrm{~T}$ he results from estimating a probit model are basically the same. We prefer a logit model just to compare the results with A hn et al. (1999).
} 
husband. Other household characteristics, such as the household size, the number of members in each labor market status and the number of children of dixerent ages in the family show no appreciable exects.

Age and Education Level: As expected, young people (aged 16-19) are more willing to work for lower wages and those aged 45 or more are much less willing to accept a reduced wage. This downward in $\ddagger$ exibility of reservation wages among old workers might rełect greater economic wealth or smaller human capital loss due to a shorter remaining working life.

The exect of education is very signi..cant. More educated workers are much less willing to work for lower wages. This may refect the labor demand situation, that is, it is harder to ..nd a job for low-educated workers, and that signaling exects (a lower current wage as lower ability) are stronger in the job market for more educated workers.

Unemployment Bene.ts: Theory predicts lower willingness among those receiving bene.ts than among non-receivers. However, although unemployment bene.ts show some negative exects on the willingness to work for lower wages, the exect is not very signi...cant. This leads us to suspect the existence of unobserved characteristics, such as experience, skill or sector, which may be correlated with bene..t receipt.

Local Labor Market Conditions: As expected, the local unemployment rate axects positively workers' willingness to work for lower wages. Those living in a location with higher unemployment are more willing to work for lower wages. However, the local vacancy rate and real wages do not show any signi..cant exects.

In summary, the results ${ }^{6}$ show that some individual characteristics, such

\footnotetext{
${ }^{6}$ In A hn et al. (1999) a similar model is estimated for the willingness to move for work. The results are similar in that the exects of age and education are both very signi..cant but the exect of unemployment bene..ts is found insigni..cant.
} 
as age and education, arect signi..cantly the workers' willingness to accept a reduced wage oxer. On the other hand, unemployment bene..ts reduce only marginally the willingness. This somewhat unexpected result may be due to unobserved heterogeneity which cannot be controlled in cross-sectional data. In the next section we will use longitudinal data to control for such heterogeneity.

\subsection{Exects of unemployment duration on the willing- ness to work for a reduced wage}

In Spain, where the proportion of long-term unemployed has been above or close to $50 \%$ during the past decade, one of the most interesting factors we can consider in examining the willingness to work for lower wages is the duration of unemployment spells. Lengthening unemployment may axect both the reservation wage, $w_{R}(t)$; and the perceived adequate wage for her quali..cation, $w^{a}$. As a worker stays unemployed longer, she is more likely to have exhausted unemployment bene..ts as well as other income sources. This is likely to lower the reservation wage, and therefore to increase the willingness to accept a reduced wage. On the other hand, perceived adequate wage, $w^{a}$, could also be adjusted downward as the unemployment spell lengthens due to, for example, the worker's skill depreciation. Hence, it is not clear how the duration of unemployment axects the willingness to work for lower wages. However, we may expect the exect on reservation wages to be greater than the other exect, therefore leading to a greater willingness to work for lower wages the longer the duration of unemployment.

First, we examine the relationship between the willingness and unemployment duration using cross-section data. Table 2a shows a simple crosstabulation between unemployment duration and the willingness obtained from the cross-section Spanish Labor Force Survey for 1992-1996. The result 
indicates no variation in the willingness by unemployment duration. This leads us to suspect the existence of uncontrolled heterogeneity among unemployed workers by unemployment duration which axects both the willingness and the duration.

Now, using a longitudinal data set, we control for unobserved individual exects to obtain more robust results on the exect of unemployment duration on the willingness to work for lower wages. In the Spanish L abor Force Survey individuals are interviewed six times (every three months over a period of one and a half years), allowing us to examine unemployed workers' willingness as their unemployment duration lengthens. For example, for those who are unemployed for two consecutive quarters, we can examine the variation of the willingness as their unemployment duration increases by three months. For the group of people who are unemployed over the entire interview period (six quarters), we can examine how the willingness changes as the duration of unemployment increases by about 15 months (time elapsed between the ..rst and the sixth interview).

Table $2 b$ shows how the willingness to work for lower wages changes as the duration of unemployment increases. All individuals in the sample were unemployed for up to 3 months at the time of their ..rst interview. We divide the sample into subgroups, each of them in a dixerent column, according to the period when individuals become employed or go out of the labor force, including a group of workers who stay unemployed over the entire time period of six interviews.

(Table $2 \mathrm{a}$ and $2 \mathrm{~b}$ )

One conclusion which can be drawn from Table $2 b$ is that the willingness indeed increases with unemployment duration. However, the increase is modest. For example, an increase by three months in the spell's duration 
raises the proportion willing to work for lower wages only by 2 percentage points. The largest increase is observed among those who are unemployed during all 6 quarters interviewed (last column of Table $2 \mathrm{~b}$ ). The proportion of workers willing to work for lower wages increases from 64 percent to 80 percent over a 15 months interval, a quarterly increase by about 3 percentage points. This relatively small sensitivity of workers' willingness to work for lower wages with respect to unemployment duration is matched by equally insensitive willingness to move for work as found in A hn et at. (1999). We can think of a few reasons for this lack of worker łexibility.

First, one might think that the responses to the question as posed in the survey could be completely random. ${ }^{7}$ In this case, individuals' responses would not depend on the duration of unemployment nor on their past responses. The second hypothesis is that the lack of variation with unemployment duration might take place because the individuals' attitude is very rigid. Maybe the attitude just does not change for whatever reason. People might maintain the same attitude regardless of their unemployment duration. In this case, the conditional probability of showing a positive or negative attitude at period $t+1$ would be, respectively, zero or one depending completely on the attitude shown in period $t$.

Both hypotheses are rejected by the transition matrix shown in Table 3 although it appears that there is a strong persistence in attitudes over time. This persistence is particularly strong among those with a positive attitude: those who show a positive attitude in one period are very likely to show the same attitude in subsequent periods. However, it seems that the attitude

\footnotetext{
${ }^{7}$ It should be kept in mind that in order to collect information on every household member the interviewer asks questions about all household members to those adults who happen to be at home at the time of the interview. This means that the information about willingness for some individuals in the survey may be based on other household members' opinion.
} 
for those with a negative attitude is not totally ..xed. In our sample about 20 percent of the unemployed workers with a negative attitude changed it to positive over a period of three months. These patterns are consistent with a theoretical prediction that the worker's reservation wages are likely to decrease with the duration of unemployment.

(Table 3)

One can think of many factors that can contribute to changing individuals' attitudes over time. As stated before, with lengthening unemployment duration people might run out of economic resources, which makes them more willing to work for lower wages. On the other hand, as unemployment spells lengthen, people somehow ..nd ways to live without a formal job. For example, if the probability of operating in the underground economy increases with unemployment duration, job oxers with lower wages become less attractive (Ahn and de la Rica, 1997), and if these workers are likely to classify themselves as unemployed in the survey, this could lead to an increase in the proportion of negative attitudes as the duration of unemployment increases. It is also possible that the preferences for work or leisure change as one spends more time unemployed. Unfortunately, in our data set we do not have much information about changes in individuals' economic situation or in their preferences.

One variable that is available for our analysis is individual status regarding unemployment bene.ts each quarter. We observe whether or not unemployed workers received unemployment bene.ts at the time of each interview. The exhaustion of unemployment bene.ts is likely to lead to a sudden (although anticipated) drop in ..nancial resources, and is likely to increase individuals' willingness to work for lower wages. ${ }^{8}$ Comparing the

\footnotetext{
${ }^{8} \mathrm{M}$ any studies have found a signi..cantly higher job-...nding probability after the exhaustion of unemployment bene.ts. See, for example, Meyer (1990) for the US and Ahn
} 
attitude of those who exhaust their unemployment bene.ts at some point between two periods with those who continue receiving them, we can examine the importance of economic means in workers' willingness to work for lower wages. A univariate comparison of the proportions changing their attitude from negative to positive between two consecutive quarters by the unemployment bene.t status shows virtually no dixerence ( $23 \%$ among those who receive bene.ts in both quarters and $24 \%$ among those who exhaust them between the two quarters). This result warrants a multivariate analysis.

Our sample consists of those workers who begin their unemployment spell unwilling to work for lower wages. We will study how the hazard rate that initially unwilling workers become willing to accept lower wages. As in any duration analysis, the estimation sample consists of two types of observations: completed and censored spells. Those who have a completed spell are the unemployed workers who change their answer from negative to at rmative during the subsequent unemployed periods observed in the survey, while the censored observations are those who have not changed their attitude from negative to positive during the observed unemployment spell. The sample characteristics are presented in Table 4. There is a high percentage of censoring, which is due to four dixerent reasons: ..nding a job (33.2\%) or leaving the labor force (26.3\%) while having a negative attitude, changing it from negative to indecision (10.2\%) or no response to the question (10.2\%).

(Table 4)

The method of estimation is based on discrete or grouped duration models (see L ancaster, 1990). The reasons for using discrete-time techniques are not only that the data are observed in discrete intervals, namely in quarters, but also that these techniques are much more fexible for estimating the timeand Ugidos (1995) for Spain, or Atkinson and Micklewright (1991) for a survey. 
dependence of the hazard rate (see Meyer, 1990). We estimate the hazard rate for the duration, $T_{R}$; until initially unwilling unemployed workers become willing to work for lower wages. The hazard rate is the following conditional probability, using a normal distribution for its estimation:

$$
\begin{aligned}
\mathrm{h}_{\mathrm{R}}(\mathrm{t} ; \mathrm{b}(\mathrm{t}) ; \mathrm{y}(\mathrm{t})) & =\operatorname{Pr}\left(\mathrm{T}_{\mathrm{R}}=\mathrm{tj} \mathrm{T}_{\mathrm{R}}, \mathrm{t} ; \mathrm{b}(\mathrm{t}) ; \mathrm{y}(\mathrm{t})\right) \\
& =\mathrm{O}\left[{ }^{\circ}{ }_{0}(\mathrm{t})+{ }^{\circ}{ }_{1}(\mathrm{t}) \mathrm{b}(\mathrm{t})+{ }^{\circ}{ }_{2}(\mathrm{t}) \mathrm{y}(\mathrm{t})\right]
\end{aligned}
$$

where, $b(t)$ is the binary indicator of whether the individual still has unemployment bene.ts in period $t$ or not, and $y(t)$ is a vector of, possibly, time-varying variables. The ${ }^{\circ}{ }_{i}(t)$ are time-varying parameters. Once the likelihood function is accordingly written, one can estimate the model using maximum likelihood techniques. ${ }^{9}$

In Table 5, we have the estimation results of this hazard rate. The ..rst result emerging from this table is the strong negative duration dependence in the hazard rate in spite of the inclusion of many variables which are supposed to capture individual heterogeneity. The time dependence of the hazard rate is estimated here with dummy variables (Dur2, ...), one for each possible duration, the duration of one quarter being absorbed in the constant term. For the mean values of all the explanatory variables, we obtain a predicted hazard which decreases by more than 10 percentage points through the ..ve quarters studied.

This result can be connected to the recent theoretical debate of whether there exists stigma or skill depreciation exects on unemployment causing a lower exit rate as the unemployment spell lengthens. ${ }^{10} \quad$ The basic idea

\footnotetext{
${ }^{9} \mathrm{~A}$ discrete duration hazard rate can be seen as a sequence of binary choice equations (with cross-equation restrictions) de..ned on the surviving population at each duration. See J enkins (1995) for a very clear explanation of these techniques.

${ }^{10}$ For this question, see Omori (1997). Dixerent models about stigma exects are in
} 
applied to our problem is that if only stigma exects are present (a longer unemployment spell signalling a bad quality), the reservation wage, but not $\mathbf{w}^{\mathrm{a}}$, will be adjusted downward with lengthening unemployment. Therefore, the probability of changing the attitude increases with unemployment duration. On the other hand, if skill depreciation exects are also present, the perceived adequate wage, wa ; will also be adjusted downwards. Hence, depending on the magnitude of both exects, the probability of changing the attitude will decrease or increase. This may be the driving force in our results above: skill depreciation is high during unemployment so that the perceived adequate wage decreases as fast as their reservation wage, and, therefore, the probability of attitude change decreases with unemployment duration.

(Table 5)

The strong negative duration dependence, however, could be also due to the presence of some heterogeneity that we do not observe. Some important unobserved variables are family income and the duration of unemployment bene..t entitlement. In the presence of unobserved heterogeneity the negative duration dependence is likely to be overestimated and, furthermore, estimated parameters could be biased. An additional bias may arise due to the endogeneity of the bene.t receipt in the case that some common unobserved factors axect both the hazard rate and the unemployment bene.t status. These problems require an adequate consideration of unobserved heterogeneity and the endogeneity of unemployment bene.t. status. ${ }^{11}$ We correct these problems by including a discrete distribution function for this heterogeneity. The results, however, are not axected by the inclusion of this Vishwanath (1989), Berkovitch (1990) or Blanchard and Diamond (1994). A model of skill depreciation can be seen in Pissarides (1992).

${ }^{11}$ See B over et al. (1997) for an explanation of these facts and of the estimation technique used here which is based, basically, on the mixture technique developed by Heckman and Singer (1984). 
heterogeneity.

W ith respect to other explanatory variables, we ..nd a large exect of education: better educated workers are less likely to change their attitude from negative to positive. However, the interaction of this variable with duration is positive and signi...cant, thus provoking the exect to change over time: those with a high education are more willing to accept lower wages when they are in unemployment for more than 9 months (see Figure 1).

The exect of age is similar to that of education but less strong and significant: although in the ..rst quarter younger workers have a lower probability of changing attitude, afterwards they are more likely than older workers.

The only household characteristic which shows a signi ..cant exect is whether the spouse works or not: those whose spouse is working have a much lower probability of changing attitude and this result does not change by gender, which contrasts with the result of the previous analysis with the pooled cross-section data.

One important variable in this study is whether the worker receives unemployment bene..ts or not. It is obtained that those individuals with unemployment bene.ts are much less likely to change their attitude from negative to positive (see Figure 2).

F inally, we also obtain a higher probability of attitude change from negative to positive in periods of recession or in regions where the unemployment rate is higher.

In summary, the results give some support to the hypotheses derived from the standard job search theory, in particular, the negative exects of unemployment bene.ts and the economic situation, and the positive exects of the local unemployment rate. The strong negative duration dependence suggests that those who begin their unemployment spells with a negative attitude 
are increasingly less likely to change their attitude over their unemployment spells. This result could be suggesting that reservation wages decrease more rapidly at the beginning of the spell than later.

\subsection{Exects of the willingness to work for lower wages on unemployment duration}

Once the dynamics of the expressed willingness to work for lower wages and its evolution along the spell of unemployment have been analyzed, we turn to the reverse causation. If this willingness is related to reservation wages, there must be some inłuence of this variable on unemployment duration. In standard job search models the exit probability from unemployment is the (instantaneous) probability of receiving an oxer times the probability of this oxer being acceptable, that is, the oxered wage being larger than the reservation wage. Numerous studies have estimated the hazard rate of leaving unemployment for the Spanish workers. ${ }^{12}$ In this section, we highlight the exect of a new variable, the expressed willingness to work for lower wages, on the worker's unemployment duration. If the willingness to work for lower wages is negatively related with reservation wages, we should expect higher exit probability among those with a positive attitude than others. It is, however, likely that the willingness also depends on the frequency of oxers one receives (more oxers, less willing to work for a reduced wage). The ultimate result depends on the magnitude of each exect. We also have to remember the presence of unobserved characteristics (income, skills, ...) which can axect both the worker's probability of leaving unemployment and the willingness. To take this into account, we will estimate jointly the hazard of leaving unemployment and a process for the willingness indicator, and at the same

\footnotetext{
${ }^{12}$ Some examples are Ahn and U gidos (1995), Cebrián et al. (1996), B over et al. (1997) or García-Pérez (1997).
} 
time we consider in both equations the presence of unobserved heterogeneity.

In order to introduce unobserved heterogeneity in this estimation, we adopt a modi..ed Heckman and Singer (1984) technique. ${ }^{13}$ We introduce a dixerent heterogeneity term in each process: ' in the unemployment hazard rate and $\grave{A}$ in the willingness indicator equation. Each unobserved heterogeneity variable is assumed to have a distribution characterized by two mass points and their expected values are assumed to be zero for identi..cation. They follow a bivariate distribution which allows dixerential exects of unobserved heterogeneity between the two processes. Hence, the two equations to be estimated are:

$$
\begin{aligned}
\mathrm{h}_{\mathrm{u}}\left(\mathrm{t} ;{ }^{\prime}\right) & =\operatorname{Pr}\left(\mathrm{T}_{\mathrm{u}}=\mathrm{tj} \mathrm{T}_{\mathrm{u}}, \mathrm{t} ; \mathrm{b}(\mathrm{t}) ; \mathrm{x}(\mathrm{t}) ; \mathrm{r}(\mathrm{t} ; \dot{\mathrm{A}}) ;{ }^{\prime}\right) \\
& =\mathrm{O}\left[{ }^{\prime}{ }_{0}(\mathrm{t})+{ }^{\prime}{ }_{1}(\mathrm{t}) \mathrm{b}(\mathrm{t})+{ }^{\prime}{ }_{2}(\mathrm{t}) \mathrm{x}(\mathrm{t})+{ }^{\prime}{ }_{3}(\mathrm{t}) \mathrm{r}(\mathrm{t} ; \grave{\mathrm{A}})+{ }^{\prime}\right] \\
\mathrm{r}(\mathrm{t} ; \grave{\mathrm{A}}) & =\operatorname{Pr}\left(\mathrm{T}_{\mathrm{r}}=\mathrm{tj} \mathrm{T}_{\mathrm{r}}, \mathrm{t} ; \mathrm{b}(\mathrm{t}) ; \mathrm{z}(\mathrm{t}) ; \grave{A}\right) \\
& =\subseteq\left[{ }^{-}(\mathrm{t})+{ }^{-}{ }_{1}(\mathrm{t}) \mathrm{b}(\mathrm{t})+{ }^{-}{ }_{2}(\mathrm{t}) \mathrm{x}(\mathrm{t})+\grave{A}\right]
\end{aligned}
$$

The hazard of leaving unemployment, $h_{u}\left(t ;{ }^{\prime}\right)$; depends not only on unemployment duration, $\mathrm{T}_{\mathrm{u}}$; observed heterogeneity, $\mathrm{b}(\mathrm{t})$ and $\mathrm{x}(\mathrm{t})$; and the willingness indicator, $r(\mathrm{t}$; $\mathrm{A})$; but also on unobserved heterogeneity, '. T The willingness depends on the duration of unemployment, $T_{r}$, observed heterogeneity, and unobserved heterogeneity, $\grave{A}:$ A s stated before, we specify a bivariate distribution for the two unobserved components, ' and À, each of them with two possible values. Given the assumption of zero expected value, we estimate four parameters: ' ${ }_{1}$ and $p$ for the heterogeneity term in the unemployment duration equation and $\grave{A}_{1}$ and $q$ in the willingness indicator equation. The

\footnotetext{
${ }^{13}$ This approach has been developed in the 1999's version (See ftp:/ / ftp.cem...es/ pdf/ papers/ sb/ dur2.pdf) of B over et al. (1997).
} 
likelihood function will be the sum over the bivariate distribution for these two variables of the likelihood for each worker in the sample. Finally, the ${ }^{\prime}{ }_{i}(\mathrm{t})$ and ${ }^{-}{ }_{i}(\mathrm{t})$ are time-varying parameters to be estimated.

We use a sample of Spanish workers who have been unemployed between 1992 and 1997. The main characteristics of the estimation sample are in Table 6. We also show Kaplan-M eier estimates in Table 7. The unemployment duration is measured in quarters since we have only quarterly information on the willingness. In Table 7 we can see that the exit rate from unemployment is larger for individuals without unemployment bene.ts and for those who are willing to accept lower wages.

(Table 6, 7)

Now we turn to the estimation results shown in Table 8. The estimated hazard is decreasing with unemployment duration ${ }^{14}$ and it is higher for workers without unemployment bene.ts. We also ..nd larger hazard rates for males and during the periods of expansion. However, we ..nd some unexpected results. For example, it seems that more educated workers have lower probabilities of leaving unemployment and that those living in regions with higher unemployment rates have a higher hazard rate. The exect of the willingness indicator is positive but only marginally signi..cant.

W ith respect to the willingness process, we obtain a rapidly decreasing probability of positive attitude as unemployment spells lengthen. This result can be interpreted in light of the previous discussion regarding stigma versus skill depreciation exects. The strong negative duration dependence suggests a dominance of the exects of skill depreciation over the exects of decreasing reservation wages along the unemployment duration.

\footnotetext{
${ }^{14} \mathrm{~T}$ he exect of unemployment duration is captured here by its absolute level. Dixerent speci..cations have been tried, including one with dummies for each possible duration. The speci..cation shown is the best in terms of likelihood function and standard errors of the coet cients.
} 
(Table 8)

The other interesting result is that, once we control for unobserved heterogeneity and endogeneity of the willingness indicator (the results without control in A ppendix A), we obtain a huge reduction in the duration dependence of the unemployment hazard rate. This result con..rms the theoretical suspicion that the negative duration dependence is overestimated when unobserved heterogeneity is not controlled for. With the technique used to estimate unobserved heterogeneity, we identify four groups of workers among which there exists one group with an estimated $12 \%$ joint probability, $\mathrm{pf} q$; of having much lower probabilities of exiting unemployment and of changing the attitude, opposite to a group with a $39.3 \%$ joint probability, $\left(1_{i} p\right) f\left(1_{i} q\right)$; of having a much higher probability of both exiting from unemployment and changing the attitude.

\section{Conclusions}

In this paper, we have examined unemployed workers' expressed willingness to accept a job with a wage lower than the one adequate for their quali..cation, and its relationship with the duration of unemployment in Spain. According to job search models, reservation wages decrease as the unemployment spell lengthens. Therefore, one should observe unemployed workers to be more willing to accept lower wages as their spells become longer.

First, we analyzed which personal and economic characteristics determine the willingness to work for a reduced wage using pooled cross-section data. The main results are that young workers, those less educated and those living in regions with high unemployment rates show a more positive attitude towards accepting lower wages while the college educated and married women with a working husband show substantially more negative attitudes. Unem- 
ployment bene..ts seem to have no exects. However, there may be important unobserved factors which warrants the analysis of longitudinal data in order to control for individual heterogeneity.

In the second part, we studied the duration until one changes her attitude from negative to positive by using a discrete-time duration model. The main results are that the hazard rate of attitude change shows a strong negative duration dependence. On the other hand, the exhaustion of unemployment bene.ts indeed shows signi..cant positive exects in the transition probability of the attitude from negative to positive.

Regarding the exects of this attitude on the exit probability from unemployment, we ..nd that the expressed willingness to work for lower wages has only a marginally signi..cant positive exect on the exit probability from unemployment. With respect to stigma versus skill depreciation exects on the length of unemployment spells, our results suggest that the exect of skill depreciation is very important.

A nother interesting result is that the negative duration dependence in the unemployment hazard rate is indeed reduced once the exect of the unobserved heterogeneity is correctly taken into account. That is, with this type of subjective variables, we can capture better the unobserved heterogeneity present in these data sets. 


\section{R eferences}

[1] Ahn N. and A. Ugidos (1995), "Duration of Unemployment in Spain: Relative Exects of Unemployment Bene.tt and Family Characteristics", Oxford Bulletin of Economics and Statistics, 57(2), 249-264.

[2] Ahn N. and S. de la Rica (1997), "The Underground E conomy in Spain: an Alternative to Unemployment?", A pplied Economics, 29, 733-743.

[3] Ahn N., S. de la Rica, and A. Ugidos (1999), "W illingness to Move for Work and Unemployment Duration in Spain", Economica, 66, 335-357.

[4] Atkinson A.B. and J. Micklewright (1991), "Unemployment Compensation and Labor Market Transitions: A Critical Review.", J ournal of Economic Literature, 29, 1679-1727.

[5] Bentolila S. and O. Blanchard (1990), "Spanish Unemployment.", E conomic Policy, 10, 233-281.

[6] Berkovitch E. (1990), "A Stigma Theory of Unemployment Duration" in: Y. Weiss and G. Fishelson, eds., Advances in the Theory and Measurement of Unemployment (M acmillan, London), 20-56.

[7] Blanchard, O. et al. (1990), Spanish Unemployment: Is There a Solution?, Center for E conomic Policy Research.

[8] Blanchard, O. and P. Diamond (1994), "Ranking, Unemployment Duration, and Wages", Review of Economic Studies, 61, pp. 417-434.

[9] Bover, O., M. A rellano and S. B entolila (1997), “Unemployment Duration, B ene.tt Duration and the Business Cycle", CEM FI Working Paper 9717. 
[10] Cebrián, I., C. García, J. Muro, L. Toharia and E. Villagómez (1996), "Protección Social y Acceso al Empleo. Un Estudio de los Perceptores de Prestaciones por Desempleo", Colección de Estudios del CES, N³4.

[11] Devine T.J . and N.M. K iefer (1991), Empirical Labor Economics: The Search A pproach, Oxford University Press: New York.

[12] García-Pérez, J . I. (1997), "Las Tasas de Salida del Empleo y el Desempleo en España (1978-1993)", Investigaciones Económicas, XXI(1), 29-53.

[13] García-Pérez, J . I. (1998), "Non-stationary J ob Search with Firing: a Structural Estimation", CEMFI Working Paper 9802.

[14] Heckman, J . and B. Singer (1984), "A Method for Minimizing the Impact of Distributional Assumptions in E conometric Models for Duration Data", Econometrica, 52, 271-320.

[15] J enkins, S. (1995), "Easy Estimation M ethods for Discrete-T ime Duration Models", Oxford Bulletin of Economics and Statistics, 57 120-138.

[16] Lancaster, T.(1990), The Econometric Analysis of Transition Data, Cambridge University Press, Cambridge.

[17] Meyer B.D. (1990), "Unemployment Insurance and Unemployment Spells", E conometrica, 58, 757-783.

[18] Mortensen, D. (1986), "J ob Search and Labor Market A nalysis", in: A shenfelter, O. C. and Layard, R., (eds.), Handbook of Labor E conomics, North-Holland, A msterdam (Vol. II), 849-919.

[19] Omori, Y. (1997), "Stigma Exects of Nonemployment", Economic Inquire, 35(2), pp. 394-416. 
[20] Pissarides, C.A. (1992), "Loss of Skill during Unemployment and the Persistence of Employment Shocks",Quarterly J ournal of Economics, 107, pp. 1371-1391.

[21] Stancanelli, E. (1999), "Do the rich stay unemployed longer? An empirical study for the UK", Oxford Bulletin of Economics and Statistics, 61, 295-314.

[22] Van den Berg, G. J . (1990), "Nonstationarity in J ob Search Theory", Review of Economic Studies, 57, 255-277.

[23] Vishwanath T. (1989), "J ob Search, Stigma Exect, and Escape Rate from Unemployment" J ournal of Labor Economics, 7-4, 487-502. 
Table 1

Logit R egression for Willingness Attitude ( $\mathrm{Yes}=1 ; \mathrm{No}=0$ )

(Data: Pooled Cross-Section EPA 1992:I-1996:I)

\begin{tabular}{|c|c|c|c|c|}
\hline \multirow[b]{2}{*}{ Variable } & \multicolumn{2}{|c|}{ Males $(\mathrm{N}=5,023)$} & \multicolumn{2}{|c|}{ Females $(\mathrm{N}=3,233)$} \\
\hline & M ean & Odds Ratio & Mean & Odds Ratio \\
\hline Spouse, head works & & & 0.26 & $0.61(2.42)$ \\
\hline Spouse, head unemp. & & & 0.09 & $1.08(0.31)$ \\
\hline Spouse, head inactive & & & 0.03 & $0.94(0.21)$ \\
\hline Child, head works & 0.23 & $0.97(0.16)$ & 0.28 & $1.07(0.26)$ \\
\hline Child, head unemp. & 0.06 & $0.73(1.50)$ & 0.05 & $0.98(0.06)$ \\
\hline Child, head inactive & 0.22 & $1.29(1.76)$ & 0.18 & $1.15(0.56)$ \\
\hline Others & 0.06 & 1.0610 & 0.04 & $0.73(1.01)$ \\
\hline A ge 16-19 & 0.13 & 1.30 & 0.17 & $1.43(2.03)$ \\
\hline A ge $20-24$ & 0.22 & $0.96(0.35)$ & 0.26 & $1.01(0.04)$ \\
\hline A ge $25-29$ & 0.22 & $1.01(0$ & 0.22 & $1.00(0.03)$ \\
\hline A ge $45+$ & 0.15 & 0.5 & 0.08 & $0.64(2.11)$ \\
\hline No Educatio & 0.12 & & 0.09 & $1.21(1.00)$ \\
\hline / Education & 0.37 & $1.03(0.38)$ & 0.22 & $1.22(1.56)$ \\
\hline Vocational Education & 0.11 & $0.92(0.67)$ & 0.16 & $0.75(2.27)$ \\
\hline Jr. & 0.02 & 0.4 & 0.06 & $0.37(5.73)$ \\
\hline University Edu & 0.03 & 0.27 & 0.06 & $0.53(3.36)$ \\
\hline Receiving Unempl. B en & 0.36 & $0.83(1.46)$ & 0.23 & $0.81(1.48)$ \\
\hline Only Registered & 0.53 & $1.08(0.67)$ & 0.61 & $1.06(0.48)$ \\
\hline Household Size & 4.41 & 1.0 & 4.28 & $0.96(0.62)$ \\
\hline \# wc & 0.77 & & 0.99 & 1.19 (1.73) \\
\hline oyed & 1.57 & 1.09 & 1.49 & $1.22(1.77)$ \\
\hline \# inactive & 1.23 & $0.87(1.76)$ & 0.91 & $0.99(0.10)$ \\
\hline Children $0-6$ years & 0.15 & $0.85(1.53)$ & 0.18 & $1.12(0.89)$ \\
\hline Child & 0.32 & & 0.34 & $1.06(0.55)$ \\
\hline Chilc & 0.22 & 0.97 & 0.18 & $1.10(0.89)$ \\
\hline Log Unemp. Rate & 2.95 & $1.57(3.19)$ & 2.90 & $1.52(2.56)$ \\
\hline Log Vacancy Rate & 3.60 & $1.08(0.45)$ & 3.56 & $1.29(1.26)$ \\
\hline Log Real Wage & 6.73 & $1.57(0.85)$ & 6.73 & $1.00(0.00)$ \\
\hline "MODEL CHI-SQUAR & & 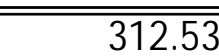 & & \\
\hline
\end{tabular}

Notes: Unsigned asymptotic t-statistics in parentheses. A lso included (but not reported) are region and year dummies. The reference category is a head of household with secondary education and aged 30 to 45. 
Table $2 a$

Workers W illing to Work for a reduced wage by U nemployment Duration

(Pooled Cross-Section EPA 1992:II-1996:II)

\begin{tabular}{l|l|l|l|l} 
Unemployment Duration (in months) & $0-5$ & $6-11$ & $12-23$ & $24-35$ \\
\hline Proportion (\%) willing & 59.4 & 59.2 & 59.2 & 61.5
\end{tabular}

Table $2 b$

Workers Willing to Work for a reduced wage by U nemployment Duration (Longitudinal EPA 1992:I-1996:II)

\begin{tabular}{|c|c|c|c|c|c|c|}
\hline \multirow{2}{*}{ Answer in the ith Interview } & \multicolumn{6}{|c|}{$\begin{array}{l}\text { Number of Quarters Unemployed } \\
\text { (starting from the } 1^{\text {st }} \text { interview) }\end{array}$} \\
\hline & 1 & 2 & 3 & 4 & 5 & 6 \\
\hline $1^{\mathrm{st}}$ & 75.4 & 69.9 & 67.7 & 66.4 & 62.1 & 63.9 \\
\hline $2^{\text {nd }}$ & & 69.6 & 70.2 & 68.4 & 63.6 & 67.1 \\
\hline $3^{\text {rd }}$ & & & 71.7 & 68.7 & 65.2 & 68.5 \\
\hline $4^{\text {th }}$ & & & & 72.3 & 70.7 & 68.8 \\
\hline $5^{\text {th }}$ & & & & & 70.9 & 71.6 \\
\hline $6^{\text {th }}$ & & & & & & 79.6 \\
\hline Avera & 75.4 & 69.8 & 68.9 & 69.9 & 66.5 & 69.9 \\
\hline Observations & 3,084 & 1,801 & 1,299 & 699 & 472 & 1,706 \\
\hline
\end{tabular}


Table 3

Transition $M$ atrix Over Three M onths Intervals (Data: Longitudinal EPA 1992:I - 1996:I.)

\begin{tabular}{l|ll}
\multirow{2}{*}{ Attitude in the First Interview } & \multicolumn{2}{|c}{ Attitude in the Second Interview } \\
& Positive & Negative \\
\hline Positive & $1,758(94 \%)$ & $108(6 \%)$ \\
Negative & $121(21 \%)$ & $459(79 \%)$
\end{tabular}


Table 4

$M$ ain Characteristics of the Sample for the Change-of-attitude Duration A nalysis (percentages in brackets)

\begin{tabular}{|c|c|c|c|c|}
\hline \multirow{2}{*}{ Duration (auarters) } & \multicolumn{2}{|c|}{ Completed Spells } & \multicolumn{2}{|c|}{ Censored Spells } \\
\hline & \multirow{2}{*}{\multicolumn{2}{|c|}{272}} & \multirow{2}{*}{\multicolumn{2}{|c|}{771}} \\
\hline 1 & & & & \\
\hline 2 & \multicolumn{2}{|c|}{66} & \multicolumn{2}{|c|}{309} \\
\hline 3 & \multicolumn{2}{|c|}{37} & \multicolumn{2}{|c|}{172} \\
\hline 4 & \multicolumn{2}{|c|}{14} & \multirow{2}{*}{\multicolumn{2}{|c|}{$\begin{array}{r}86 \\
238\end{array}$}} \\
\hline 5 & & & & \\
\hline A ge 16-19 & 55 & (13.85) & 187 & $(11.86)$ \\
\hline A ge $20-24$ & 90 & (22.67) & 383 & (24.31) \\
\hline A ge $25-29$ & 71 & (17.88) & 277 & (17.64) \\
\hline A ge $30-45$ & 109 & (27.45) & 459 & (29.12) \\
\hline Age $45+$ & 72 & (18.13) & 269 & (17.06) \\
\hline No Education & 98 & $(24.68)$ & 427 & $(27.10)$ \\
\hline Primary Education & 182 & $(45.84)$ & 672 & (42.64) \\
\hline Vocational Education & 74 & (18.64) & 265 & (16.88) \\
\hline J r. College Education & 23 & (5.79) & 109 & (6.98) \\
\hline University Education & 20 & (5.04) & 101 & (6.43) \\
\hline Male & 234 & $(58.94)$ & 967 & (61.36) \\
\hline Spouse working & 40 & $(10.07)$ & 212 & $(13.45)$ \\
\hline Spouse unemployed & 113 & $(28.46)$ & 406 & $(25.76)$ \\
\hline Spouse inactive & 244 & (61.46) & 958 & (60.78) \\
\hline With bene..ts & 147 & (37.02) & 588 & (37.31) \\
\hline TOTAL & 397 & & 1,576 & \\
\hline
\end{tabular}


Table 5

Estimation of the Change-of-attitude Hazard R ate with Endogenous Unemployment Bene..ts (controlling for unobserved heterogeneity)

\section{$\underline{\text { Hazard Estimation }}$}

\begin{tabular}{l|r|r} 
Parameter & Coeđ cient & t-ratio \\
\hline \hline & -1.253 & 8.16 \\
Constant & -0.503 & 5.33 \\
Dur 2 & -0.687 & 4.77 \\
Dur 3 & -1.083 & 4.91 \\
Dur 4 & -1.345 & 4.89 \\
Dur 5 & -0.352 & 2.09 \\
\hline High Education & 0.142 & 1.79 \\
Durationf High E ducation & -0.223 & 1.87 \\
\hline Young & 0.098 & 1.63 \\
Durationf Young & -0.330 & 1.78 \\
\hline Spouse Working & 0.126 & 1.42 \\
Durationf Spouse Work. & -0.127 & 1.08 \\
\hline Male & 0.069 & 1.18 \\
Durationf Male & -0.318 & 2.05 \\
\hline Bene..ts & -0.030 & 1.64 \\
\hline 4 GDP & 0.014 & 3.10 \\
Regional Unempl. Rate & -0.014 & 0.16 \\
\hline Second Quarter & 0.194 & 2.36 \\
Third Quarter & 0.025 & 0.30 \\
Fourth Quarter & &
\end{tabular}

Unobserved Heterogeneity coe..cients:

$\begin{array}{lrr}\text { Pr } & 0.742 & 1.70 \\ 1 & 0.217 & 0.91 \\ 2 & -0.626 & \end{array}$


Table 5 (Cont.)

Estimation of the Change-of-attitude $\mathrm{H}$ azard $\mathrm{R}$ ate with Endogenous Unemployment Bene..ts (controlling for unobserved heterogeneity)

\begin{tabular}{l|r|r}
\multicolumn{2}{c}{ Process for B ene.ts R eceipt } \\
Parameter & Coec cient & t-ratio \\
\hline \hline & & \\
Constant & -1.589 & 7.37 \\
Dur 2 & 1.271 & 12.64 \\
Dur 3 & 1.458 & 10.32 \\
Dur 4 & 1.455 & 8.40 \\
Dur 5 & 0.977 & 5.68 \\
\hline Low Education & 0.129 & 1.79 \\
Young & -0.132 & 1.61 \\
With experience & 1.550 & 8.45 \\
Male & 0.240 & 2.93 \\
\hline 4 GDP & 0.036 & 1.26 \\
4 Regional Unempl. Rate & 0.028 & 1.37 \\
\hline \# unemployed & -0.055 & 1.23 \\
Children 0-6 years & -0.147 & 2.47 \\
Household Size & 0.032 & 1.53 \\
\hline Spouse & -0.286 & 2.58 \\
Son & -0.633 & 6.18 \\
Other relative & -0.489 & 3.30
\end{tabular}

Note: Log-likelihood $=-2,732.55$, Number of observations $=4,050$. 
Table 6

$M$ ain Characteristics of the Sample for the U nemployment Duration A nalysis (percentages in brackets)

\begin{tabular}{|c|c|c|c|c|}
\hline & \multicolumn{2}{|c|}{ Completed Spells } & \multicolumn{2}{|c|}{ Censored Spells } \\
\hline \multirow{6}{*}{$\begin{array}{r}\text { Quarters } \\
1 \\
2 \\
3 \\
4 \\
5\end{array}$} & \multirow{2}{*}{\multicolumn{2}{|c|}{2,091}} & \\
\hline & & & \multicolumn{2}{|c|}{1,001} \\
\hline & \multicolumn{2}{|c|}{1,178} & \multicolumn{2}{|c|}{491} \\
\hline & \multicolumn{2}{|c|}{852} & \multicolumn{2}{|c|}{355} \\
\hline & \multicolumn{2}{|c|}{432} & & 35 \\
\hline & \multicolumn{2}{|c|}{281} & \multicolumn{2}{|c|}{2,089} \\
\hline A ge $<30$ & 2,859 & $(13.85)$ & 2,326 & $(56.44)$ \\
\hline A ge $30-45$ & 1,352 & $(22.67)$ & 1,272 & $(30.87)$ \\
\hline A ge $45+$ & 623 & (17.88) & 523 & (12.69) \\
\hline No Education & 1,489 & $(30.80)$ & 1,058 & $(25.67)$ \\
\hline Primary Education & 2,283 & $(47.23)$ & 1,791 & (43.46) \\
\hline Vocational Education & 684 & (14.15) & 752 & (18.25) \\
\hline J r. College Education & 237 & $(4.90)$ & 313 & (7.59) \\
\hline University Education & 141 & $(2.92)$ & 207 & $(5.02)$ \\
\hline Males & 3,377 & $(68.86)$ & 2,325 & $(56.42)$ \\
\hline Spouse working & 723 & $(14.96)$ & 555 & $(13.46)$ \\
\hline Spouse unemployed & 928 & (19.20) & 1,075 & $(26.08)$ \\
\hline Spouse inactive & 3,183 & (65.85) & 2,491 & $(60.45)$ \\
\hline With bene..ts & 2,083 & (43.09) & 1,750 & $(42.46)$ \\
\hline W illing to accept & 3,201 & $(66.22)$ & 2,830 & $(68.67)$ \\
\hline TOTAL & 4,834 & & 4,121 & \\
\hline
\end{tabular}


Table 7

K aplan-M eier Hazard R ates for the Duration in Unemployment (percentages)

\begin{tabular}{c|c|c|c|c|c} 
Quarter & Sample & $\begin{array}{c}\text { With } \\
\text { Unempl. Bene.ts }\end{array}$ & $\begin{array}{c}\text { Without } \\
\text { Unempl. Bene.ts }\end{array}$ & $\begin{array}{c}\text { Willing } \\
\text { to accept }\end{array}$ & $\begin{array}{c}\text { Not willing } \\
\text { to accept }\end{array}$ \\
\hline & & & & & \\
1 & 23.35 & 18.86 & 26.71 & 23.55 & 23.07 \\
2 & 20.09 & 18.53 & 21.22 & 20.82 & 18.66 \\
3 & 20.31 & 20.01 & 20.49 & 21.32 & 17.96 \\
4 & 14.46 & 15.16 & 14.10 & 15.05 & 12.95 \\
5 & 11.85 & 12.48 & 11.57 & 12.55 & 9.89
\end{tabular}


Table 8

Estimation of the Unemployment Hazard R ate with Endogenous Willingness I ndicator (controlling for unobserved heterogeneity)

\section{$\underline{\text { Hazard Estimation }}$}

\begin{tabular}{l|r|r} 
Parameter & Coeф cient & t-ratio \\
\hline \hline & -1.120 & 12.78 \\
Constant & -0.027 & 0.96 \\
Dur & 0.245 & 5.03 \\
\hline Without Studies & 0.217 & 4.83 \\
Incompleted Primary Education & 0.114 & 2.27 \\
Complete Primary Education & -0.436 & 11.82 \\
\hline Bene.ts & 0.035 & 1.39 \\
\hline Willingness & 0.417 & 12.07 \\
\hline Male & 0.022 & 1.84 \\
4 GDP & 0.005 & 2.51 \\
Regional Unempl. Rate & -0.022 & 2.62 \\
4 Regional Unempl. Rate & 0.036 & 1.28 \\
\hline Second Quarter & -0.001 & 0.01 \\
Third Quarter & -0.102 & 3.51 \\
Fourth Quarter & & \\
& & \\
Unobserved Heterogeneity coe..cients: & & \\
p & & \\
, & 0.255 & 2.43 \\
1 2 & -1.192 & 2.18
\end{tabular}


Table 8 (Cont.)

Estimation of the Unemployment Hazard R ate with Endogenous Willingness Indicator (controlling for unobserved heterogeneity)

\begin{tabular}{l|r|r}
\multicolumn{3}{c}{ Process for W Wllingnes Indicator } \\
\cline { 2 - 2 } Parameter & Coeф cient & t-ratio \\
\hline \hline & -1.053 & \\
Constant & -0.135 & 4.13 \\
Dur & -0.039 & 0.77 \\
\hline Bene.ts & 0.424 & 5.26 \\
\hline Without Studies & 0.273 & 3.62 \\
Incomplete Primary Education & 0.279 & 3.29 \\
Complete Primary E ducation & 0.295 & 4.28 \\
\hline A ge < 30 & 0.294 & 4.09 \\
A ge 30-45 & 0.083 & 6.66 \\
\hline 4 GDP & 0.036 & 10.30 \\
R egional Unempl. Rate & 0.048 & 1.77 \\
\hline \# unemployed without bene.ts & 0.191 & 2.92 \\
Spouse unemployed & -0.074 & 1.59 \\
\hline Second quarter & -0.125 & 2.59 \\
Third quarter & 0.008 & 0.18 \\
Fourth quarter & -0.179 & 1.91
\end{tabular}

Unobserved Heterogeneity coe..cients:

$\begin{array}{lrr}q & 0.472 & 20.76 \\ \dot{A}_{1} & -1.250 & 16.56 \\ \dot{A}_{2} & 1.119 & \end{array}$

Note: Log-likelihood $=-20,042.7$, Number of observations $=24,369$. The reference category is an unemployed worker with secondary or more studies. 


\section{A ppendix $A$}

Table A 1

Estimation of the Unemployment Hazard R ate and the $\mathrm{W}$ illingness Indicator (without controlling for unobserved heterogeneity)

Hazard Estimation

\begin{tabular}{l|r|r} 
Parameter & Coeđ cient & t-ratio \\
\hline \hline & & \\
Constant & -0.815 & 14.58 \\
Dur & -0.110 & 14.96 \\
\hline Without Studies & 0.191 & 5.25 \\
Incompleted Primary Education & 0.175 & 5.14 \\
Complete Primary Education & 0.094 & 2.40 \\
\hline B ene.ts & -0.307 & 12.78 \\
\hline Willingness & 0.037 & 1.85 \\
\hline Male & 0.309 & 15.35 \\
\hline 4 GDP & 0.021 & 2.19 \\
Regional Unempl. Rate & 0.004 & 2.77 \\
4 Regional Unempl. Rate & -0.015 & 2.25 \\
\hline Second Quarter & 0.033 & 1.30 \\
Third Quarter & -0.003 & 0.13 \\
Fourth Quarter & -0.091 & 3.51
\end{tabular}

Note: Log-likelihood $=-11,783.01$, Number of observations $=24,369$. The reference category is an unemployed worker with secondary or more studies. 
Table A 1 (Cont.)

Estimation of the Unemployment $\mathrm{H}$ azard R ate and the Willingness Indicator (without controlling for unobserved heterogeneity)

\begin{tabular}{l|r|r}
\multicolumn{3}{c}{ Process for W Wllingnes Indicator } \\
\cline { 2 - 2 } Parameter & Coec cient & t-ratio \\
\hline \hline & -0.242 & 3.19 \\
Constant & -0.545 & 42.62 \\
Dur & -0.038 & 1.32 \\
\hline B ene.ts & 0.246 & 5.74 \\
\hline Without Studies & 0.161 & 4.09 \\
Incomplete Primary E ducation & 0.139 & 3.08 \\
Complete Primary Education & 0.145 & 3.95 \\
\hline A ge < 30 & 0.150 & 3.89 \\
A ge 30-45 & 0.053 & 7.97 \\
\hline 4 GDP & 0.021 & 11.79 \\
R egional Unempl. Rate & 0.051 & 2.97 \\
\hline \# unemployed without bene..ts & 0.116 & 2.76 \\
Spouse unemployed & -0.062 & 1.96 \\
\hline Second quarter & -0.057 & 1.81 \\
Third quarter & 0.024 & 0.79 \\
Fourth quarter & -0.092 & 1.66
\end{tabular}

Note: Log-likelihood $=-8,419.57$, Number of observations $=14,482$. The reference category is an unemployed worker with secondary or more studies. 
Figure 1: Predicted Hazard by Education

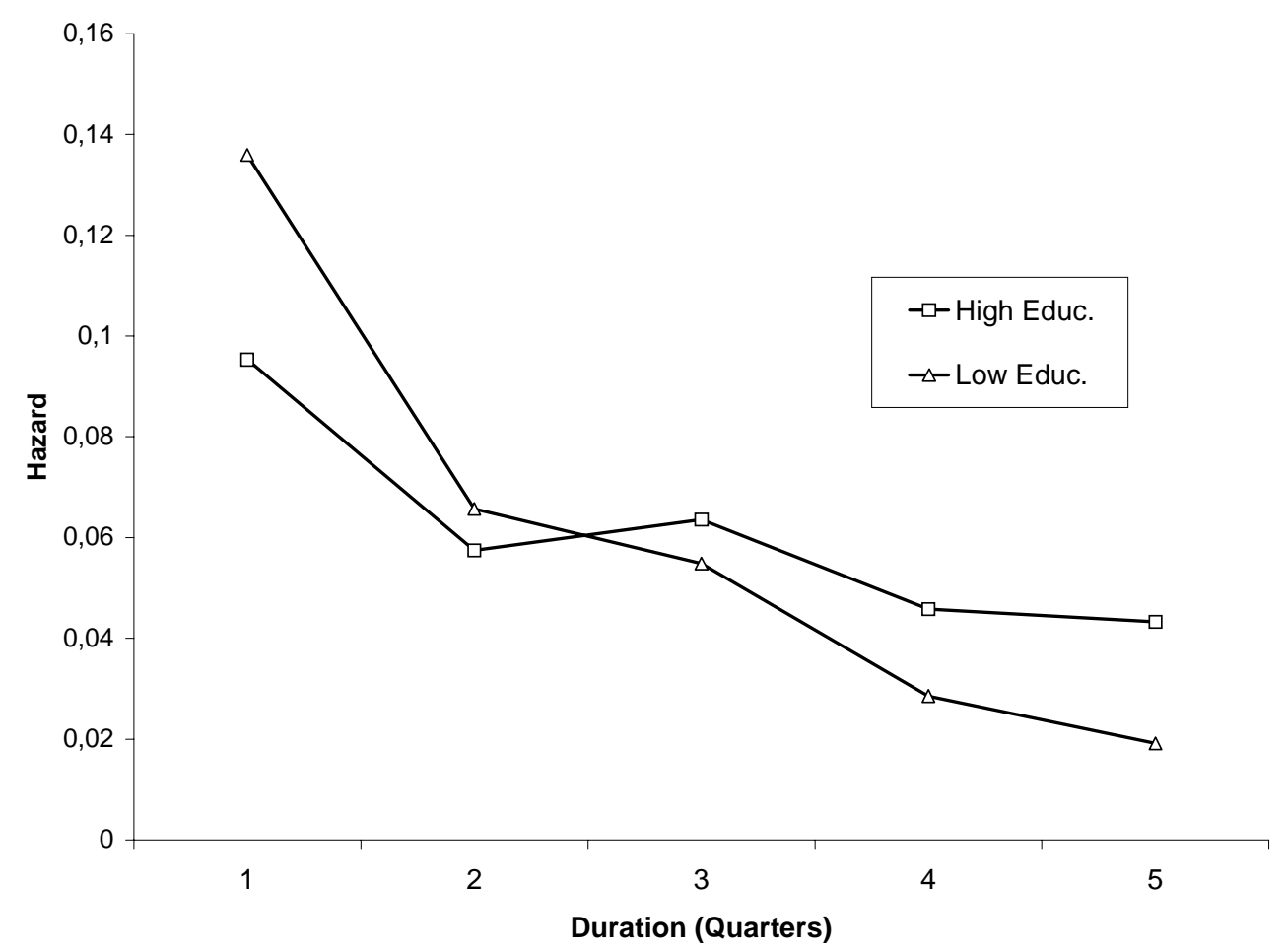


Figure 2: Predicted Hazard and Benefits

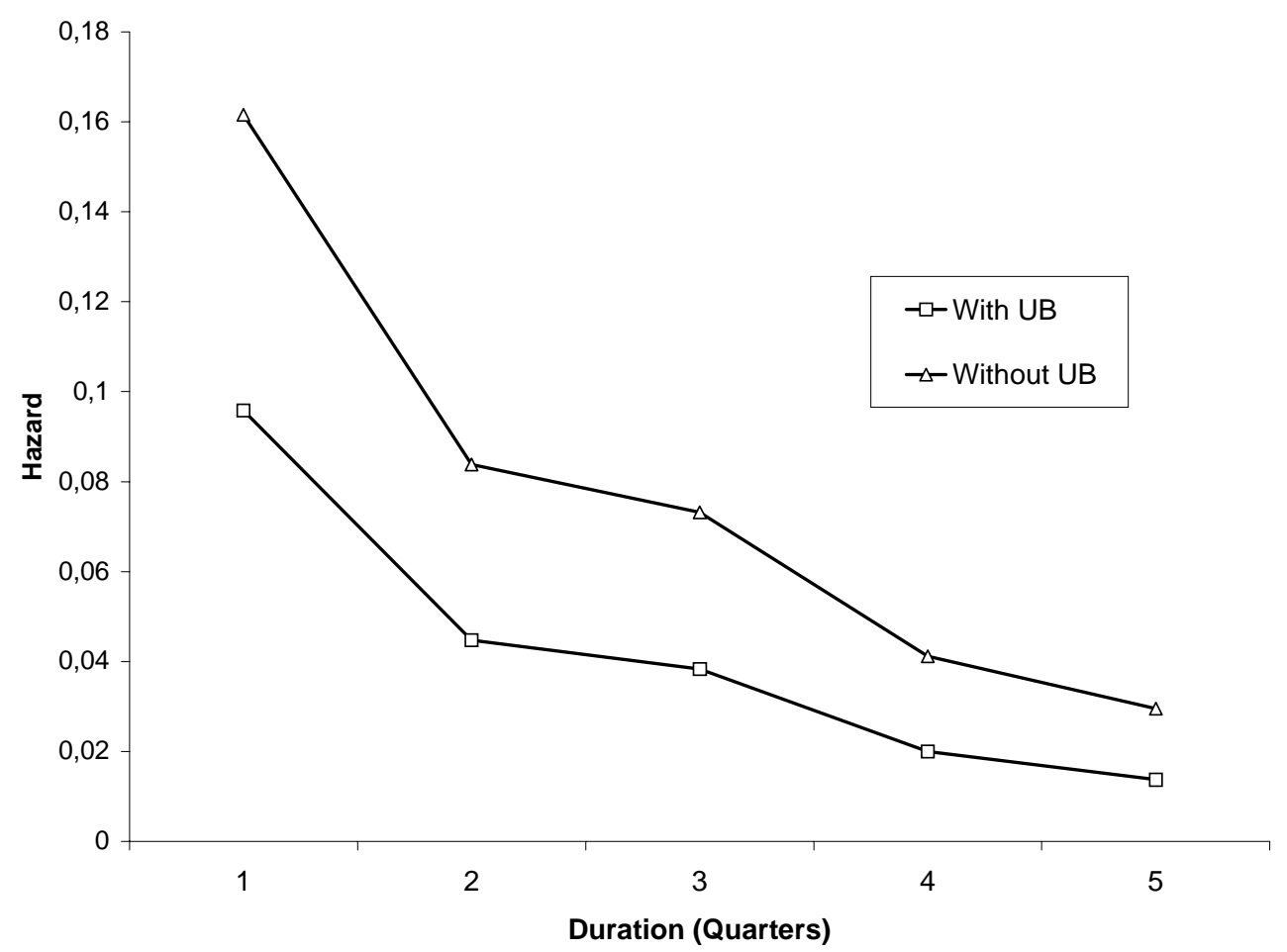

